\title{
Russula farinipes Romell apud Britzelmayr in Finland
}

\author{
Railisuominen
}

In the summer of 1965 Dr. Hans HaAs from Stuttgart visited Finland. At that time he presented me with a fungus, which he had found in Turku, Ruissalo, and which I had not seen before. The fungus concerned was Russula farinipes Rom. In September 1966 I became more familiar with the species, both in a beech forest in Southwest Germany as well as under the microscope, again with the introduction of Dr. HaAs.

In the autumn of 1966 I also got in my hands two specimens - represented in the Turku University Herbarium - with the provisory names $R$. fellea Fr.? and R. sp., which can presumably be taken to refer to the same species. R. fellea Fr. and R. farinipes Rom. came at once into my mind. The species proved to be the latter one. Because there are no earlier notes of its existence in Finland it might be useful to record it.

SGHaeffer (s. 267) defines the species as follows.

«Ein scharfer Weissporer. Blassocker-semmelgelb \pm körnigrauh, scharfrandig. Lamellen schmal sichelig. Stiel blass, flockig, ausspitzend. Fleisch hart und sehr elastisch, sehr scharf, geruchlos. Sporen isoliert punktiert, I a. Cystiden in Lamellen, Hut und Stiel pfriemlich spitz. Laubwald.«

According to the literature and the specimens I have seen $R$. farinipes could be described as follows. The pellicle of the cap is chamois-like, not only because of the colour,

During the printing Dr. Veikko Hintikka sent me from HFR. Herbarium a specimen of $R$. farinipes collected by him in Bromarv (VarsinaisSuomi) in the famous oak forest of Framnäs 29. VIII. 1964. The sizes of the spores of these specimens are

$$
7,54 \pm 0,031 \times 5,99 \pm 0,021 \mu \text { (50 spores). }
$$

but also because of the floccose upper surface. From the striate margin stripes may continue elsewhere in the cap. The cap sometimes has a Lactarius-like umbo, but may be funnel shaped. The flesh is thin, but hard and flexible, white in colour and acrid in taste (most like R. sardonia Fr. in my opinion). The gills have the tint of the cap. They are pale, elastic, not especially wide, becoming narrower both toward the margin and toward the stipe, and are often decurrent. The flocci on the light straw-coloured stem are seen as a granular surface (the name!) with the naked eye and microscopically as pointed cystidia on the stem, gills and cap, and their awl-like shape is a conspicuous characteristic. The stipe is elastic, its inside has cavities when old. The spores are small, 6-8 u (Schrf.) \pm smooth, with isolated spines.

Both specimens (Turku, Ruissalo 11 VIII 1966 leg. Ulla Laaksonen and Kemiö, Viik 10 IX 1966 leg. Esteri Kankainen) were determined when dry and they have been compared with South German specimens of $R$. fellea and $R$. farinipes as well as with the literature.

The greatest difficulty in determination was to differentiate these two species. $R$. fellea has a smoother pellicle, the margin of the cap is more rounded, the gills break more easily, the smell is fruit-like and nauseous, the surface of the stem is smooth, the spores are larger $(8-9(11) \times 7-8 \mu)$ and more decorated than those of $R$. farinipes. The cystidia on the stipe are cone-shaped. The size, light yellowish colour and acrid taste are common to both species. $R$. farinipes has white sporepowder, while the sporepowder of R. fellea is pale. But the difference is very 
slight if the spore deposit happens to be scanty.

Macroscopically the fungus concerned is $R$. farinipes. An easily noticeable characteristic among other things is the floccose surface and narrowing base of the stem. In the specimens from Viik even the cap is floccose, in that from Ruissalo especially the top of the stem. In the margin the pellicle is broken from dryness and there are rusty spots on it as well because of old age. An especially prominent feature is the pointed form of the cystidia. Nevertheless the spores are more decorated than in the pictures by Schaeffer and they could have been interpreted to represent $R$. fellea as well. They are more like the pictures by LANGE (1940, 18:4:D and $18: 6: \mathrm{A})$, in which the difference between those species is not as clear. LANGE also mentions the small size of the spores, with which the specimens agree.

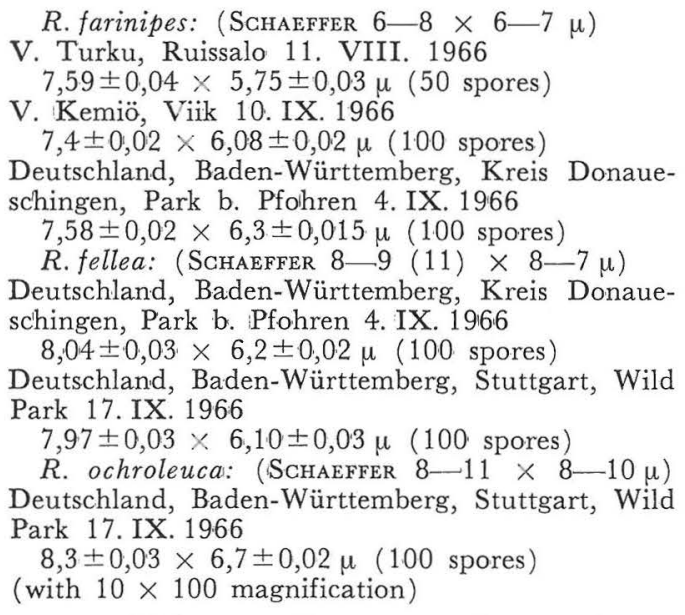

In addition to Schaeffer the specimens agree with the shorter descriptions by PEARSON and LANGE. In the new book by RoMAGNESi there are some more well described details and a thorough account of the microscopic features of $R$. farinipes. I could not find anything against placing the specimens in this species.

The fungus can hardly be confused with other Finnish species. R. ochroleuca Pers. and $R$. foetens Fr. (R. laurocerasii Melz.) can slightly resemble it. $R$. foetens is usually larger, more viscid, lighter in colour, has an unpleasant smell and is easy to recognize at least by its spores. $R$. ochroleuca is brighter yellow, sometimes with a greenish tint, the cuticle is smoother, the margin more rounded, the gills and stem whiter than in $R$. farinipes. The tops of the cystidia on the stipe are more rounded and the spores are big.

Among the Middle European species it is difficult to distinguish between $R$. farinipes Rom. and $R$. pectinata Fr. sensu Cooke and its group.

The name $R$. farinipes is given by Romell. According to Schaeffer it is partly the same as $R$. pectinata by FrIEs, so that the species might occur in Sweden. I could not find it in the list by Lundell \& NANNFELDT. Schaeffer has learned to know this species from fungi found in the areas of Stuttgart and Brandenburg (the former ones mainly sent by HaAs). In Denmark the fungus is not uncommon, especially in copses of Quercus and Corylus (Lange, 1940).

The places where the Finnish specimens have been found agree with what has been said in the literature about the habitat of $R$. farinipes. The species is known to appear mostly in deciduous forests. R. fellea occurs mostly in beech forests. Both Ruissalo and Viik represent the southernmost Finnish forest zone with Quercus and Corylus. The specimen from Ruissalo was found in a Picea grove. $R$. farinipes completes the list of species in our Quercus zone (cf. Kallio, 1963).

\section{LITERATURE}

HintıkкA, V., 1964. Retkeilijän sieniopas. 245 pp. Helsinki.

Kallio, P., 1963. Zur Verbreitung einiger in Finnland südlichen Pilze besonders in der südwestlichen Eichenzone. Karstenia 6-7, pp. $35-76$.

Lange, J., 1940. Flora Agaricina Danica V, 106 pp: Lundell, S. \& J. A. Nannfeldt 1934-1959. Fungi Exsiccati Suecici, praesertim Upsalienses. Uppsala.
Pearson, A. A., 1950. The Genus Russula. 2nd ed. 24 pp. London. Hull.

Romagnesi, H., 1967. Les Russules d'Europe et d'Afrique du Nord. 998 pp. Bordas.

Schaeffer, J., 1952. Russula - Monographie Die Pilze Mitteleuropas. III. 296 pp. Bad Heilbrunn.

Tuomikoski, R., 1953. Sienet värikuvina. 246 pp. Porvoo, Helsinki. 